\title{
A method for the production of D-tagatose using a recombinant Pichia pastoris strain secreting $\beta$-D-galactosidase from Arthrobacter chlorophenolicus and a recombinant $\mathrm{L}$-arabinose isomerase from Arthrobacter sp. 22c
}

Marta Wanarska ${ }^{1,2^{*}}$ and Józef Kur ${ }^{1,2}$

\begin{abstract}
Background: D-Tagatose is a natural monosaccharide which can be used as a low-calorie sugar substitute in food, beverages and pharmaceutical products. It is also currently being tested as an anti-diabetic and obesity control drug. D-Tagatose is a rare sugar, but it can be manufactured by the chemical or enzymatic isomerization of D-galactose obtained by a $\beta$-D-galactosidase-catalyzed hydrolysis of milk sugar lactose and the separation of D-glucose and D-galactose. L-Arabinose isomerases catalyze in vitro the conversion of D-galactose to D-tagatose and are the most promising enzymes for the large-scale production of D-tagatose.

Results: In this study, the araA gene from psychrotolerant Antarctic bacterium Arthrobacter sp. 22c was isolated, cloned and expressed in Escherichia coli. The active form of recombinant Arthrobacter sp. 22c L-arabinose isomerase consists of six subunits with a combined molecular weight of approximately $335 \mathrm{kDa}$. The maximum activity of this enzyme towards D-galactose was determined as occurring at $52^{\circ} \mathrm{C}$; however, it exhibited over $60 \%$ of maximum activity at $30^{\circ} \mathrm{C}$. The recombinant Arthrobacter sp. 22C L-arabinose isomerase was optimally active at a broad pH range of 5 to 9 . This enzyme is not dependent on divalent metal ions, since it was only marginally activated by $\mathrm{Mg}^{2+}, \mathrm{Mn}^{2+}$ or $\mathrm{Ca}^{2+}$ and slightly inhibited by $\mathrm{Co}^{2+}$ or $\mathrm{Ni}^{2+}$. The bioconversion yield of $\mathrm{D}$-galactose to $\mathrm{D}$-tagatose by the purified L-arabinose isomerase reached $30 \%$ after $36 \mathrm{~h}$ at $50^{\circ} \mathrm{C}$. In this study, a recombinant Pichia pastoris yeast strain secreting $\beta$-D-galactosidase Arthrobacter chlorophenolicus was also constructed. During cultivation of this strain in a whey permeate, lactose was hydrolyzed and D-glucose was metabolized, whereas D-galactose was accumulated in the medium. Moreover, cultivation of the P. pastoris strain secreting $\beta$-D-galactosidase in a whey permeate supplemented with Arthrobacter sp. 22c L-arabinose isomerase resulted in a 90\% yield of lactose hydrolysis, the complete utilization of D-glucose and a 30\% conversion of D-galactose to D-tagatose.

Conclusions: The method developed for the simultaneous hydrolysis of lactose, utilization of D-glucose and isomerization of D-galactose using a $P$. pastoris strain secreting $\beta$-D-galactosidase and recombinant L-arabinose isomerase seems to offer an interesting alternative for the production of D-tagatose from lactose-containing feedstock.
\end{abstract}

\footnotetext{
* Correspondence: marwanar@pg.gda.pl

${ }^{1}$ Department of Microbiology, Chemical Faculty, Gdańsk University of

Technology, Narutowicza 11/12, 80-233, Gdańsk, Poland

BLIRT S.A., Trzy Lipy 3/1.38, 80-172, Gdańsk, Poland
} 


\section{Background}

D-Tagatose is a rare natural ketohexose, a C-4 epimer of $\mathrm{D}$-fructose and an isomer of aldohexose D-galactose. It occurs naturally as a component of the gum exudate of the tropical tree Sterculia setigera [1]. D-Tagatose is also found in small amounts in dairy products such as in-container sterilized cow's milk [2], UHT lactosehydrolyzed milk [3], and various cheeses and yogurts [4]. This monosaccharide is readily soluble in water $\left(58 \% \mathrm{w} / \mathrm{w}\right.$ at $\left.21^{\circ} \mathrm{C}\right)$, stable at a $\mathrm{pH}$ range of 2 to 7 , and has sweet taste similar to that of sucrose. DTagatose is $92 \%$ as sweet as sucrose, but its caloric value is much lower, at $1.5 \mathrm{kcal} / \mathrm{g}$ for humans, which is $37.5 \%$ of the caloric value of sucrose $(4 \mathrm{kcal} / \mathrm{g}$ ) [5]. Moreover, D-tagatose has a greater sweetness and lower caloric value than many mono- and disaccharides, namely D-glucose, D-galactose, lactose and maltose, and most of the sugar alcohols widely used as low-calorie sweeteners [6]. Since D-tagatose has received GRAS (Generally Recognized as Safe) approval from the U.S. Food and Drug Administration, it can be used in confectionery, beverages and dietary products as a low-calorie sweetener. D-Tagatose has been also approved as a food ingredient in Australia, New Zealand, Brazil, Korea, Japan and the European Union. Furthermore, D-tagatose has numerous health and medical benefits, including prebiotic, antioxidant and tooth-friendly properties. It is also safe for diabetics [5]. According to the WHO (World Health Organization), 346 million people worldwide have diabetes, $90 \%$ of whom suffer from type 2 . D-Tagatose is currently being tested as a potentially important new drug for treating type 2 diabetes and obesity [7].

D-Tagatose can be produced by the oxidation of Dgalactitol using microorganisms like Arthrobacter globiformis [8], Mycobacterium smegmatis [9], Enterobacter agglomerans [10] or Gluconobacter oxydans [11,12]. The maximum yield from biotransformation has been reported as being 92\% [10]. However, this process cannot be used for large-scale D-tagatose production because of the high cost and unavailability of D-galactitol as a raw material. A method for producing D-tagatose by the bioconversion D-psicose using various strains of Mucoraceae fungi has also been described [13]. DPsicose is a rare sugar, but it can be produced by the epimerization of relatively cheap raw material D-fructose using D-tagatose 3-epimerase from Pseudomonas cichorii [14] or Rhodobacter sphaeroides [15], as well as D-psicose 3-epimerase from Agrobacterium tumefaciens [16]. However, the method for producing D-tagatose from D-fructose via D-psicose seems to have little potential for commercial application.

Isomerization of $\mathrm{D}$-galactose is an economically viable method for D-tagatose production. D-Galactose can be isomerized chemically or enzymatically. The chemical method for D-tagatose production was developed and patented by Biospherics Incorporated (USA). According to the patent, D-galactose can be isomerized to Dtagatose with calcium hydroxide and in the presence of calcium chloride as a catalyst. Under strongly alkaline conditions, and at a relatively low temperature, calcium hydroxide forms an insoluble complex with D-tagatose. Treatment of the suspension with acid, preferably carbon dioxide, liberates $\mathrm{D}$-tagatose from the complex. The insoluble calcium salt is then removed by filtration. The remaining ions are eliminated by ion exchange chromatography. The crude syrup is then concentrated, and the pure D-tagatose is recovered by crystallization [17]. The chemical method does, however, have some disadvantages, such as by-product and chemical waste formation. The process is also energy-consuming, since it requires intensive cooling of the reaction mixture.

The enzymatic method of producing D-tagatose from $\mathrm{D}$-galactose uses L-arabinose isomerase as a biocatalyst. In vivo L-arabinose isomerase (EC 5.3.1.4) catalyzes the conversion of L-arabinose to L-ribulose, which is the first step of this aldopentose metabolism in bacteria with arabinose operon. This enzyme is also able to isomerize $\mathrm{D}$-galactose to D-tagatose, in vitro. Several microorganisms have been reported as sources of L-arabinose isomerases. Active enzymes towards D-galactose were isolated from mesophiles such as Escherichia coli [18], Bacillus halodurans [19], Lactobacillus plantarum [20] and Lactobacillus fermentum [21]; thermophiles such as Geobacillus stearothermophilus [19], Geobacillus thermodenitrificans [22], Bacillus stearothermophilus US100 [23], Bacillus stearothermophilus IAM11001 [24], Alicyclobacillus acidocaldarius [25], Anoxybacillus flavithermus [26], Thermus sp. IM6501 [27], Acidothermus cellulolytics [28] and Thermoanaerobacter mathranii [29]; and hyperthermophiles like Thermotoga neapolitana [30] and Thermotoga maritima [31]. An Larabinose isomerase from psychrotolerant bacterium Lactobacillus sakei $23 \mathrm{~K}$ has also recently been described [32]. Most of these enzymes are optimally active at elevated temperatures ranging from 60 to $95^{\circ} \mathrm{C}$ and at a $\mathrm{pH}$ of above 7; only L-arabinose isomerase from $L$. sakei $23 \mathrm{~K}$ exhibits optimum activity at low temperatures ranging from 30 to $40^{\circ} \mathrm{C}$ and at a $\mathrm{pH}$ range of 5 to 7 . Moreover, almost all the L-arabinose isomerases characterized require divalent metal ions such as $\mathrm{Mn}^{2+}$ or $\mathrm{Co}^{2+}$ for high activity and stability, with L-AI from mesophilic bacterium $B$. halodurans being the only one which is not dependent on them. However, the industrial application of $\mathrm{L}$-arabinose isomerase requires an acidic $\mathrm{pH}$ and relatively low temperatures in order to reduce by-product formation and save energy [25]. Furthermore, the isomerization reaction should be conducted without the 
addition of divalent metal ions, especially $\mathrm{Co}^{2+}$ ions, as these are unacceptable in food applications.

Both the chemical and enzymatic methods for producing D-tagatose use D-galactose as a substrate. DGalactose can be obtained from the hydrolysis of pure lactose or lactose-containing materials such as whey or whey permeate, both of them plentiful and inexpensive dairy industry by-products. In most of the processes described, lactose is enzymatically hydrolyzed using commercially available $\beta$-D-galactosidases from Aspergillus sp. $[17,33,34]$. The mixture of D-glucose and D-galactose is then separated by means of chromatography and the pure D-galactose is isomerized [17,34]. D-Glucose and $\mathrm{D}$-galactose can be also separated by selective fermentation of D-glucose using Saccharomyces cerevisiae yeast [33]. However, this process should be strictly monitored and completed directly after D-glucose utilization, since S. cerevisiae is also able to ferment $\mathrm{D}$-galactose.

For these reasons, new, simple methods of D-tagatose production are still sought. The present study was conducted with a view to developing a single-step method for producing D-tagatose directly from whey permeate. To this end, a recombinant Pichia pastoris yeast strain secreting $\beta$-D-galactosidase from Arthrobacter chlorophenolicus was constructed and a recombinant Larabinose isomerase from psychrotolerant bacterium Arthrobacter sp. 22c was obtained and characterized. The combination of the recombinant yeast strain and the enzyme in one reaction mixture containing whey permeate resulted in the simultaneous hydrolysis of lactose, the utilization of D-glucose and the isomerization of D-galactose to D-tagatose.

\section{Results}

\section{Selection and identification of strain $22 c$, producing} L-arabinose isomerase

In order to select a microorganism producing Larabinose isomerase with high activity at a low temperature, twenty bacterial strains previously isolated from Antarctic soil samples were grown, in an LBS medium containing L-arabinose, for the induction of ara $A$ gene expression. The enzyme activity in the cell extracts was then determined at $25^{\circ} \mathrm{C}$ and $\mathrm{pH} 7.0$, using $\mathrm{D}$-galactose as a substrate. The cell extracts of only three isolates named 22c, 32b and 32c exhibited L-arabinose isomerase activity. The bioconversion yields of $\mathrm{D}$ galactose to D-tagatose obtained after $24 \mathrm{~h}$ were 2.75 , 1.24 and $1.28 \%$ for cell extracts of strains $22 \mathrm{c}, 32 \mathrm{~b}$ and $32 \mathrm{c}$, respectively. The bacterial strain named 22c was selected for further study because of the highest Larabinose isomerase activity. This isolate also exhibited amylase activity, but $\beta$-D-galactosidase, lipase/esterase and protease activities were absent. The optimum growth of strain $22 \mathrm{c}$ was observed at 24 to $26^{\circ} \mathrm{C}$ and no growth occurred at $37^{\circ} \mathrm{C}$. Hence, isolate $22 \mathrm{c}$ can be categorized as a psychrotolerant microorganism.

The genus of strain 22c was assessed on the basis of the 16S ribosomal DNA gene sequence. An alignment of the 16S rDNA gene of isolate 22c (GenBank, accession no. JN642527) with the sequences available in the GenBank database demonstrated that strain 22c should be classified as an Arthrobacter sp.

\section{Cloning, expression and purification of Arthrobacter sp. 22c L-arabinose isomerase}

The degenerated primers araDF and araAR were designed on the basis of the sequences and genetic organization of arabinose operons from Arthrobacter sp. FB24, Arthrobacter aurescens TC1 and Arthrobacter chlorophenolicus A6 (araB, araD and araA). A 1362 bp DNA fragment obtained by PCR using those primers contained 1134 bp fragment of putative Arthrobacter sp. $22 \mathrm{c}$ ara $A$ gene. The unknown part of the gene encoding $\mathrm{L}$-arabinose isomerase adjacent to the known sequence was found using the GenomeWalker ${ }^{\mathrm{TM}}$ Universal Kit

Table 1 Comparison of the amino acid sequence of Arthrobacter sp. 22c L-arabinose isomerase with amino acid sequences of $L$-arabinose isomerases from various microorganisms

\begin{tabular}{|c|c|c|c|}
\hline Organism & $\begin{array}{l}\text { GenBank } \\
\text { Accession } \\
\text { No. }\end{array}$ & $\begin{array}{l}\text { Identity } \\
\text { (\%) }\end{array}$ & $\begin{array}{l}\text { Similarity } \\
(\%)\end{array}$ \\
\hline Arthrobacter sp. FB24 & ABK01625 & 71.1 & 89.1 \\
\hline Arthrobacter chlorophenolicus A6 & ACL38380 & 69.7 & 88.2 \\
\hline Arthrobacter aurescens TC1 & ABM06985 & 69.5 & 88.6 \\
\hline $\begin{array}{l}\text { Acidothermus cellulolytics } \\
\text { ATCC } 43068\end{array}$ & ACZ67491 & 59.3 & 83.4 \\
\hline Bacillus stearothermophilus US100 & CAI29261 & 54.6 & 81.3 \\
\hline Geobacillus stearothermophilus & AAD45718 & 54.6 & 81.3 \\
\hline Anoxybacillus flavithermus & AEE98871 & 54.6 & 81.1 \\
\hline Alicyclobacillus acidocaldarius & AAY68209 & 54.4 & 81.1 \\
\hline Thermus sp. IM6501 & AAO72082 & 54.2 & 80.7 \\
\hline Geobacillus thermodenitrificans & AAQ72737 & 54.0 & 80.9 \\
\hline $\begin{array}{l}\text { Bacillus stearothermophilus } \\
\text { IAM } 11001\end{array}$ & ABY84698 & 53.8 & 80.7 \\
\hline Thermotoga neapolitana & AAK18729 & 52.8 & 78.7 \\
\hline Thermotoga maritima & AAD35365 & 52.0 & 77.6 \\
\hline Bacillus halodurans & BAB05592 & 50.3 & 79.3 \\
\hline $\begin{array}{l}\text { Escherichia coli str. K-12 } \\
\text { substr. W3110 }\end{array}$ & BAB96631 & 50.0 & 79.1 \\
\hline Lactobacillus sakei $23 \mathrm{~K}$ & CAl56163 & 48.5 & 75.0 \\
\hline Lactobacillus plantarum NC8 & CCC80517 & 48.3 & 74.4 \\
\hline Lactobacillus fermentum CGMCC2921 & ADJ94948 & 43.7 & 71.9 \\
\hline Thermoanaerobacter mathranii & CAE46769 & 25.1 & 59.8 \\
\hline
\end{tabular}

A homology search was performed using version 3 of the FASTA programme at the EBI (European Bioinformatics Institute). 
(See figure on previous page.)

Figure 1 Multiple sequence alignment of Arthrobacter sp. 22c L-arabinose isomerase with other L-arabinose isomerases. 22cAl Arthrobacter sp. 22C L-Al, ACAI - Acidothermus cellulolytics ATCC 43068 L-Al, TSAI - Thermus sp. IM6501 L-Al, BStAl - Bacillus stearothermophilus IAM 11001 L-Al, BSAI - Bacillus stearothermophilus US100 L-Al, GSAI - Geobacillus stearothermophilus L-Al, AFAl - Anoxybacillus flavithermus L-Al, AAAI - Alicyclobacillus acidocaldarius L-AI, GTAI - Geobacillus thermodenitrificans L-AI, BHAI - Bacillus halodurans L-Al, TNAI - Thermotoga neapolitana L-Al, TMAI - Thermotoga maritima L-Al, ECAI - Escherichia coli str. K-12 substr. W3110 L-Al, LPAI - Lactobacillus plantarum NC8 L-Al, LFAI - Lactobacillus fermentum CGMCC2921 L-Al, LSAI - Lactobacillus sakei $23 \mathrm{~K} \mathrm{L-Al,} \mathrm{TaMAI} \mathrm{-} \mathrm{Thermoanaerobacter} \mathrm{mathranii} \mathrm{L-Al.} \mathrm{Three} \mathrm{levels} \mathrm{of}$ conserved residues are indicated by blue (100\%), green (80\%) and yellow (60\%) backgrounds. Catalytic residues are shaded red. The alignment was performed using Clustalx 2.0.11 program.

(Clontech Laboratories, USA). Analysis of the sequences obtained revealed an open reading frame consisting of 1,512 bp, which encoded a 503 amino acid protein with a calculated molecular mass of $55,183 \mathrm{Da}$ and a theoretical pI of 5.08 (ProtParam; ExPASy Proteomics Server). A homology search, performed using the BLAST (Basic Local Alignment Search Tool) at the NCBI (National Center for Biotechnology Information) displayed a 71, 70 and $69 \%$ identity with nucleotide sequences corresponding to the araA genes from Arthrobacter sp. FB24, Arthrobacter chlorophenolicus A6 and Arthrobacter aurescens TC1, respectively. The Arthrobacter sp. 22c araA gene product showed a $71.1 \%$ amino acid identity and an $89.1 \%$ similarity with L-arabinose isomerase from Arthrobacter sp. FB24, a $69.7 \%$ identity and an $88.2 \%$ similarity with L-AI from $A$. chlorophenolicus A6, and a $69.5 \%$ identity and an $88.6 \%$ similarity with L-AI from $A$. aurescens TC1. Furthermore, the Arthrobacter sp. 22c L-arabinose isomerase displayed a higher sequence identity with L-AIs from thermophilic bacteria such as Acidothermus cellulolytics ATCC 43068, Bacillus stearothemophilus US100, Geobacillus stearothermophilus, Anoxybacillus flavithermus, Alicyclobacillus acidocaldarius, Thermus sp. IM6501, Geobacillus thermodenitrificans and Bacillus stearothermophilus IAM 11001 than those from mesophiles like $\mathrm{Ba}$ cillus halodurans, Escherichia coli, Lactobacillus plantarum NC8 and Lactobacillus fermentum CGMCC2921 or the psychrotolerant Lactobacillus sakei $23 \mathrm{~K}$ (Table 1). The multiple sequence alignment of Arthrobacter sp. 22c L-arabinose isomerase (22cAI) with its previously described counterparts from psychrotolerant, mesophilic, thermophilic and hyperhtermophilic microorganisms revealed some conserved regions and four essential catalytic residues, namely E307, E334, H351 and $\mathrm{H} 451$, corresponding to the E306, E333, H350 and H450 of $E$. coli L-arabinose isomerase and the E306, E331, H348 and H447 of B. stearothermophilus US100 L-AI (Figure 1) $[35,36]$.

In order to produce and investigate the biochemical properties of Arthrobacter sp. 22c L-arabinose isomerase, a recombinant pET30araA22c plasmid was constructed and used for the expression of the Arthrobacter sp. 22c araA gene in E. coli BL21(DE3)pLysS. The recombinant enzyme was purified by means of ion exchange chromatography using weak and strong anion exchangers. After purification and following sodium dodecyl sulfate-polyacrylamide gel electrophoresis and staining with Coomassie blue, large quantities of protein were observed migrating between 45 and $66 \mathrm{kDa}$ (Figure 2, lane 4). This concurred with the molecular mass of Arthrobacter sp. 22c L-arabinose isomerase deduced from the nucleotide sequence of araA gene $(55.2 \mathrm{kDa})$. The overexpression system and purification method applied were quite efficient, yielding $48 \mathrm{mg}$ (Table 2) of Arthrobacter sp. 22c L-arabinose

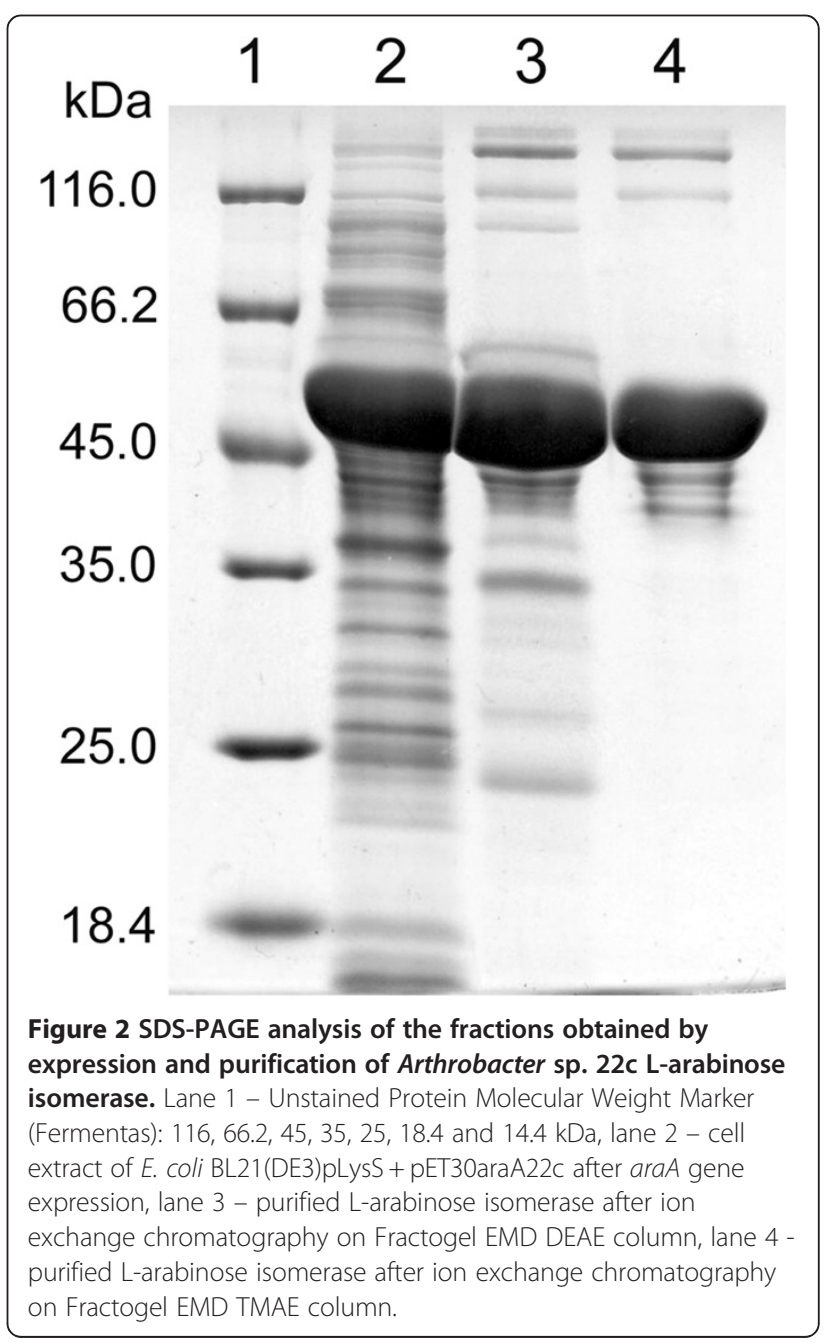


Table 2 Summary of the purification of recombinant Arthrobacter sp. 22c L-arabinose isomerase obtained from $1 \mathrm{~L}$ of E. coli BL21(DE3)pLysS culture

\begin{tabular}{lccccc}
\hline Purification step & Protein $(\mathbf{m g})$ & Total activity $(\mathbf{U})$ & Specific activity $\left.\mathbf{( U \mathbf { ~ m g }} \mathbf{- 1}^{\mathbf{1}}\right)$ & Purification (fold) & Recovery $(\%)$ \\
\hline Cell extract & 490 & 12.76 & 0.026 & 1.0 & 100 \\
Fractogel EMD DEAE & 105 & 11.60 & 0.110 & 4.2 & 21 \\
Fractogel EMD TMAE & 48 & 11.14 & 0.232 & 8.9 & 10 \\
\hline
\end{tabular}

The enzyme activity was measured with D-galactose as a substrate.

isomerase from $1 \mathrm{~L}$ of $E$. coli culture. The molecular mass of the native enzyme, estimated by gel filtration, was $335 \mathrm{kDa}$. Hence, it is assumed that the Arthrobacter sp. 22c Larabinose isomerase is probably a hexameric protein.

\section{Properties of Arthrobacter sp. 22c L-arabinose isomerase} Investigation into the effect of temperature on Arthrobacter sp. 22c L-arabinose isomerase showed that the highest isomerization activity with $\mathrm{D}$-galactose as a substrate occurred at $52^{\circ} \mathrm{C}$; however, the enzyme exhibited over $60 \%$ of maximum activity at $30^{\circ} \mathrm{C}$ (Figure 3 ).

The Arthrobacter sp. 22c L-arabinose isomerase showed high stability at $50^{\circ} \mathrm{C}$ and $\mathrm{pH} 7.0$, since over $90 \%$ of its initial activity was retained after $72 \mathrm{~h}$ incubation. At 60 and $65^{\circ} \mathrm{C}$, over $50 \%$ of initial activity was lost in incubations of 60 and $30 \mathrm{~min}$, respectively. The enzyme was completely inactivated by $15 \mathrm{~min}$ at $70^{\circ} \mathrm{C}$.

In order to determine the optimum $\mathrm{pH}$ for recombinant L-arabinose isomerase activity, conversion of Dgalactose to $\mathrm{D}$-tagatose was performed at various $\mathrm{pH}$ values and at $50^{\circ} \mathrm{C}$. The enzyme exhibited maximum activity at $\mathrm{pH} 8.0$ and maintained over $90 \%$ of maximum activity in a pH range of 5 to 9 (Figure 4).

For examination of the metal ion requirements, the purified 22cAI was treated with $10 \mathrm{mM}$ EDTA in order to remove metal ions, dialyzed against $20 \mathrm{mM}$ HEPES
pH 7.0 and then assayed in the presence of $\mathrm{Ca}^{2+}, \mathrm{Co}^{2+}$, $\mathrm{Mg}^{2+}, \mathrm{Mn}^{2+}$ and $\mathrm{Ni}^{2+}$ ions. No activity loss was observed after treatment with EDTA for $12 \mathrm{~h}$. The enzyme was marginally activated by $\mathrm{Mg}^{2+}, \mathrm{Mn}^{2+}$ and $\mathrm{Ca}^{2+}$ ions, and slightly inhibited by $\mathrm{Co}^{2+}$ and $\mathrm{Ni}^{2+}$ ions (Table 3).

The kinetic parameters of Arthrobacter sp. 22c Larabinose isomerase for D-galactose as a substrate were determined at $50^{\circ} \mathrm{C}$ and $\mathrm{pH}$ 7.0. The $K_{\mathrm{m}}, V_{\max }$ and catalytic efficiency $\left(k_{\mathrm{cat}} / K_{\mathrm{m}}\right)$ were $119 \mathrm{mM}, 0.31 \mathrm{U} \mathrm{mg}^{-1}$ and $0.14 \mathrm{mM}^{-1} \mathrm{~min}^{-1}$, respectively.

Production of D-tagatose from D-galactose by Arthrobacter sp. 22c L-arabinose isomerase demonstrated that the conversion of D-galactose to D-tagatose reached equilibrium after $36 \mathrm{~h}$ incubation $\left(\mathrm{pH} 7.0,50^{\circ} \mathrm{C}\right)$, with a conversion ratio of $30 \%$ (Figure 5 ).

\section{Construction and characterization of a recombinant Pichia pastoris strain secreting $\beta$-D-galactosidase Arthrobacter chlorophenolicus}

In order to construct a recombinant Pichia pastoris strain secreting $\beta$-D-galactosidase Arthrobacter chlorophenolicus, the gene encoding $\beta$-D-galactosidase was cloned under the control of a constitutive glyceraldehyde 3-phosphate dehydrogenase $(G A P)$ promoter in the form of translational fusion with the Saccharomyces cerevisiae $\alpha$-factor leader sequence. The recombinant pGAPZ $\alpha$ -

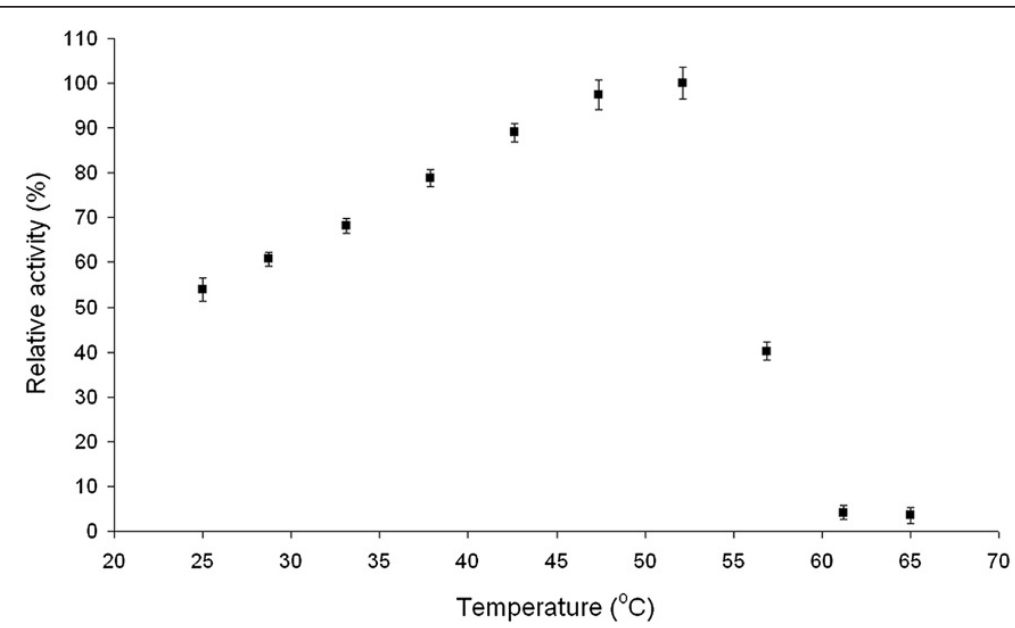

Figure 3 Effect of temperature on activity of recombinant Arthrobacter sp. 22c L-arabinose isomerase. Reaction mixtures containing $0.2 \mathrm{mg} \mathrm{mL}^{-1}$ Arthrobacter sp. 22c L-arabinose isomerase and 4\% (w/v) D-galactose in $20 \mathrm{mM}$ potassium phosphate buffer pH $7.0 \mathrm{were}$ incubated at temperatures from 25 to $65^{\circ} \mathrm{C}$ for $12 \mathrm{~h}$. 


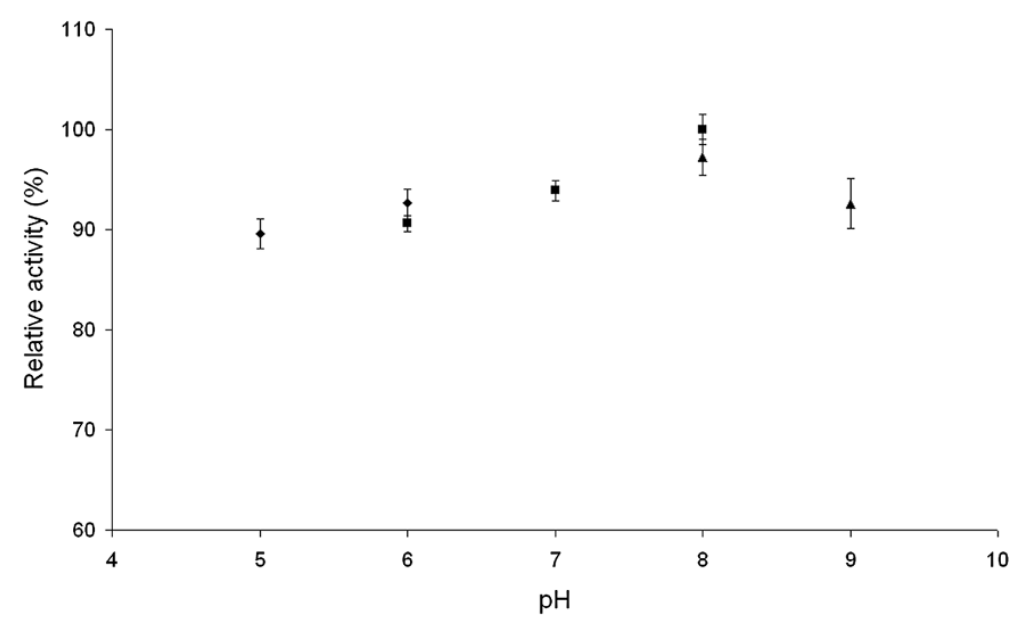

Figure 4 Effect of pH on activity of recombinant Arthrobacter sp. 22c L-arabinose isomerase. Reaction mixtures containing $0.2 \mathrm{mg} \mathrm{mL}^{-1}$ Arthrobacter sp. 22c L-arabinose isomerase and 4\% (w/v) D-galactose in $20 \mathrm{mM}$ citrate buffer pH 5-6 (\$), $20 \mathrm{mM}$ potassium phosphate buffer pH 6-8 (- $)$ and $20 \mathrm{mM}$ Tris- $\mathrm{HCl}$ buffer $\mathrm{pH} 8-9(\mathbf{\Delta})$ were incubated at $50^{\circ} \mathrm{C}$ for $12 \mathrm{~h}$.

$\beta$-galAch plasmid was then used to transform the P. pastoris competent cells. The recombinant yeast strain obtained was able to grow in a medium containing lactose as the sole carbon source. Moreover, growing the recombinant $P$. pastoris strain secreting $\beta$-Dgalactosidase in the whey permeate resulted in the hydrolysis of lactose and utilization of D-glucose, while D-galactose was accumulated in the medium. The efficient hydrolysis of lactose, at approximately $90 \%$ and production of $\mathrm{D}$-galactose was achieved in a whey permeate containing up to $120 \mathrm{~g} \mathrm{~L}^{-1}$ lactose (Figure $6 \mathrm{~A}$ and $\mathrm{B}$ ), after $168 \mathrm{~h}$ at $30^{\circ} \mathrm{C}$. However, the higher concentrations of lactose in the cultivation medium resulted in lower yields of hydrolysis (Figure $6 \mathrm{C}$ and D), and the formation of galactooligosaccharides.

\section{Production of D-tagatose using the Pichia pastoris strain secreting $\beta$-D-galactosidase Arthrobacter chlorophenolicus and the recombinant Arthrobacter sp. 22c L-arabinose isomerase}

D-Tagatose was obtained by simultaneous production and isomerization of $\mathrm{D}$-galactose. The recombinant $P$.

Table 3 Effects of metal ions on Arthrobacter sp. 22c L-arabinose isomerase activity

\begin{tabular}{lccc}
\hline $\begin{array}{l}\text { Concentration of } \\
\text { metal ions }\end{array}$ & $\mathbf{1 ~} \mathbf{~} \mathbf{M}$ & Relative activity (\%) & \\
\cline { 2 - 3 } & 100 & $\mathbf{5} \mathbf{~ m M}$ & $\mathbf{1 0} \mathbf{~ m M}$ \\
\hline None & $109 \pm 1.8$ & 100 & 100 \\
$\mathrm{Ca}^{2+}$ & $94 \pm 1.5$ & $105 \pm 2.2$ & $94 \pm 1.2$ \\
$\mathrm{Co}^{2+}$ & $110 \pm 0.3$ & $109 \pm 0.1$ & $110 \pm 1.0$ \\
$\mathrm{Mg}^{2+}$ & $106 \pm 6.5$ & $105 \pm 0.2$ & $105 \pm 0.1$ \\
$\mathrm{Mn}^{2+}$ & $81 \pm 0.4$ & $76 \pm 0.3$ & $70 \pm 0.4$ \\
$\mathrm{Ni}^{2+}$ & & & \\
\hline
\end{tabular}

pastoris strain secreting $\beta$-D-galactosidase $A$. chlorophenolicus was grown in a whey permeate containing $110 \mathrm{~g} \mathrm{~L}^{-1}$ lactose at $30^{\circ} \mathrm{C}$ with agitation. After $48 \mathrm{~h}$, when the lactose was partially hydrolyzed and $\mathrm{D}$-galactose was present in the medium, at a quantity of $28 \mathrm{~g} \mathrm{~L}^{-1}$, the purified L-arabinose isomerase Arthrobacter sp. 22c was added to an amount of $0.2 \mathrm{mg} \mathrm{mL}^{-1}$ and cultivation was continued for $120 \mathrm{~h}$. As shown in Figure 7, after $144 \mathrm{~h}$ of cultivation, the conversion of D-galactose into Dtagatose had reached equilibrium and the concentrations of lactose, D-galactose and D-tagatose in the medium were 10.6, 34.4 and $14.8 \mathrm{~g} \mathrm{~L}^{-1}$, respectively, corresponding to a $90 \%$ yield of lactose hydrolysis and $30 \%$ yield of D-galactose bioconversion.

\section{Discussion}

The article has described the cloning, purification and characterization of L-arabinose isomerase from psychrotolerant Antarctic bacterium Arthrobacter sp. 22c. This enzyme exists in the solution as a hexamer, similarly to $\mathrm{L}$-arabinose isomerases from mesophilic bacteria $E$. coli or L. plantarum NC8, although most of the L-AIs characterized to date are tetramers (Table 4).

The Arthrobacter sp. 22c L-arabinose isomerase is optimally active at relatively low temperatures ranging from 47 to $52^{\circ} \mathrm{C}$ and it exhibits high activity at an acidic $\mathrm{pH}$. These features make this it attractive for the conversion of D-galactose into D-tagatose, since there is no formation of undesirable by-products and it allows energy to be saved. Only one L-arabinose isomerase, which was isolated from the psychrotolerant bacterium L. sakei $23 \mathrm{~K}$, has similar properties (Table 4). However, the latter enzyme needs $\mathrm{Mn}^{2+}$ or $\mathrm{Mg}^{2+}$ ions for maximum activity and stability, whereas the Arthrobacter sp. 22c $\mathrm{L}$-arabinose isomerase does not require the addition of 


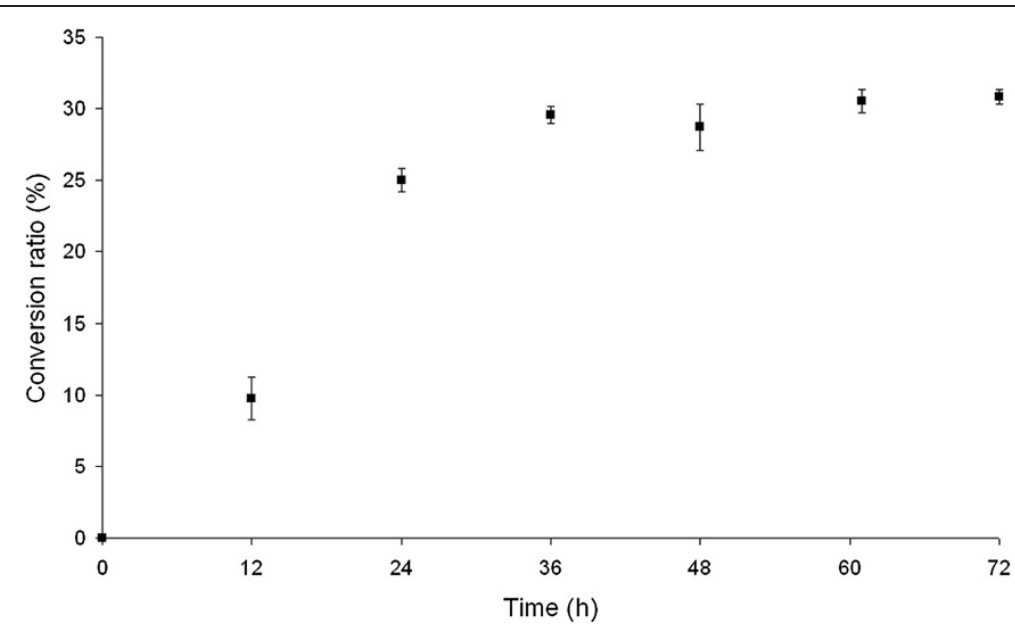

Figure 5 Time course of D-tagatose production during Arthrobacter sp. 22c L-Al-catalyzed isomerization of D-galactose. Reaction mixtures containing $0.2 \mathrm{mg} \mathrm{mL}^{-1}$ Arthrobacter sp. 22c L-arabinose isomerase and 4\% (w/v) D-galactose in $20 \mathrm{mM}$ potassium phosphate buffer pH 7.0 were incubated at $50^{\circ} \mathrm{C}$.

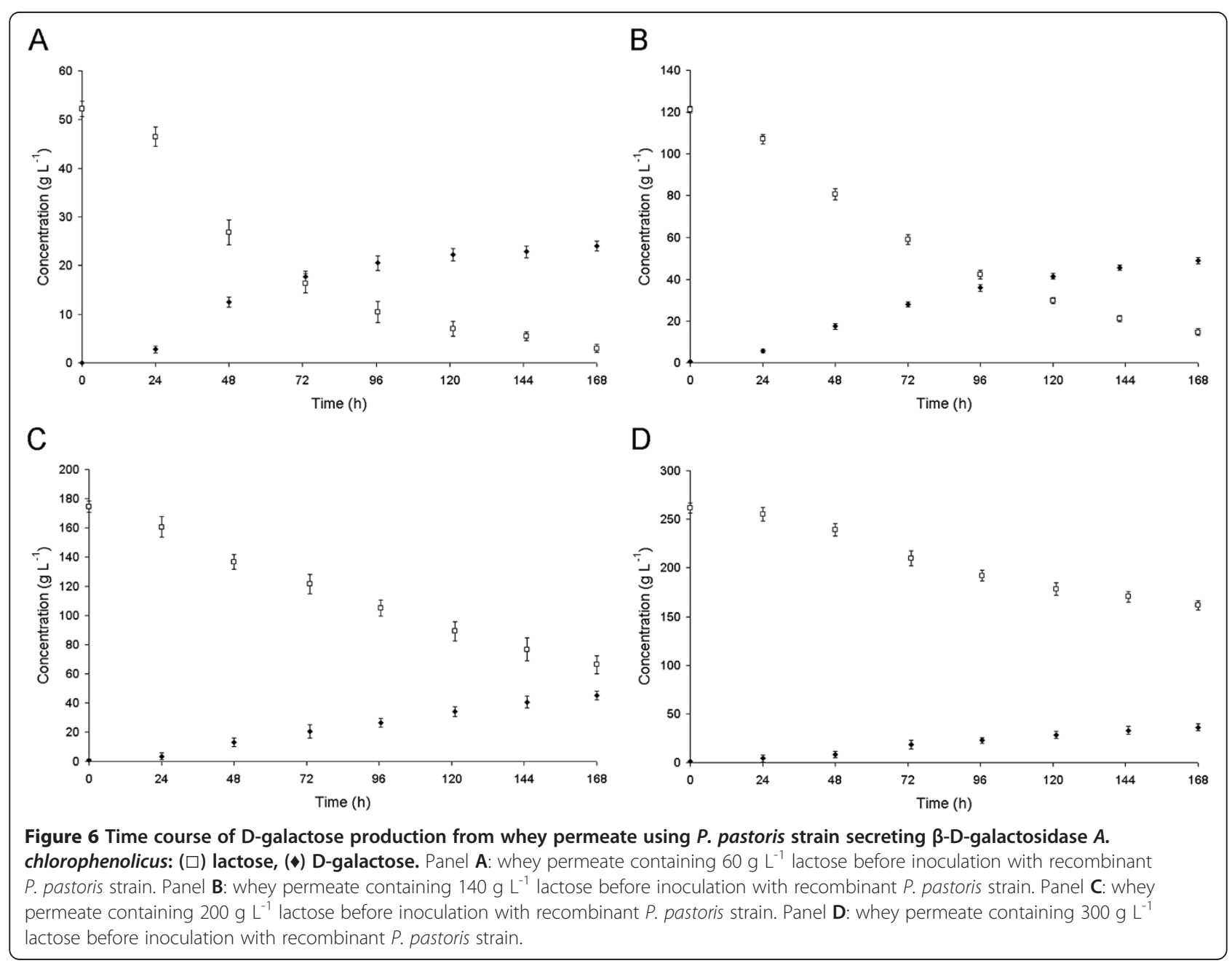




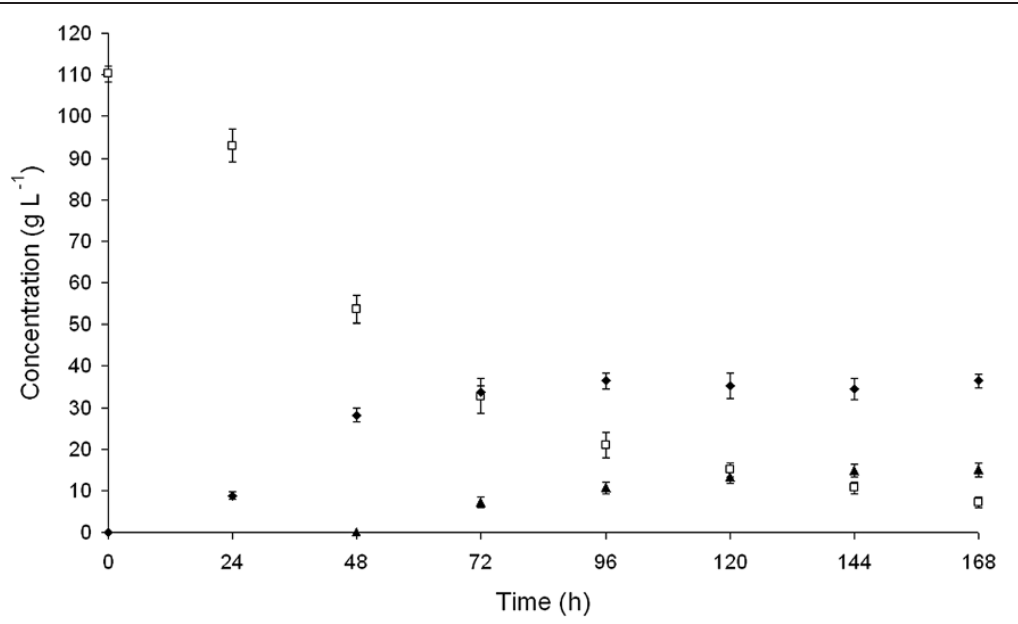

Figure 7 Time course of $D$-tagatose production from whey permeate using $P$. pastoris strain secreting $\beta$-D-galactosidase $A$.

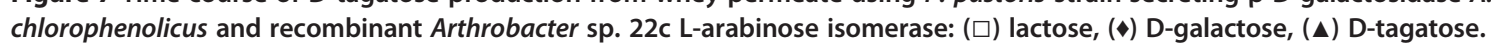

divalent metal ions to the reaction mixture for high activity and stability. The main disadvantage of 22cAI is the relatively low D-galactose bioconversion rate of $30 \%$ as compared to others L-arabinose isomerases, especially those which are thermostable (Table 5). However, the authors suppose that D-tagatose production yield can be increased by mutagenesis of 22cAI, as has been achieved in the case of the L-arabinose isomerase from $G$. thermodenitrificans [40].
The article also presents the construction and characterization of a recombinant $P$. pastoris strain secreting $\beta$-D-galactosidase from psychrotolerant bacterium A. chlorophenolicus [41]. P. pastoris yeast was selected for this study owing to its inability to metabolize D-galactose. $P$. pastoris lacks the enzymes constituting the Leloir pathway such as galactokinase, galactose-1-phosphate uridylyltransferase and UDPgalactose 4-epimerase (KEGG PATHWAY Database).

Table 4 Biochemical properties of L-arabinose isomerases from various microorganisms

\begin{tabular}{|c|c|c|c|c|c|c|}
\hline Organism & $\begin{array}{l}\text { Molecular mass } \\
(\mathrm{kDa})\end{array}$ & $\begin{array}{l}\text { Oligomeric } \\
\text { state }\end{array}$ & $\begin{array}{l}T_{\text {opt }} \\
\left({ }^{\circ} \mathrm{C}\right)\end{array}$ & $\mathrm{pH}_{\mathrm{opt}}$ & $\begin{array}{l}\text { Metal ion } \\
\text { requirement }\end{array}$ & References \\
\hline Arthrobacter sp. 22c & $335(55.2)^{a}$ & 6 & $47-52$ & $5.0-9.0$ & Not required & This study \\
\hline Lactobacillus sakei $23 \mathrm{~K}$ & $220(53.7)^{\mathrm{a}}$ & 4 & $30-40$ & $5.0-7.0$ & $\mathrm{Mn}^{2+}, \mathrm{Mg}^{2+}$ & 32 \\
\hline Escherichia coli & $362(56.0)^{a}$ & 6 & 30 & 8.0 & $\mathrm{Fe}^{2+}, \mathrm{Mn}^{2+}$ & 18,37 \\
\hline Bacillus halodurans & $224(56.3)^{a}$ & 4 & 50 & $7.5-8.0$ & Not required & 19 \\
\hline Lactobacillus plantarum NC8 & $342(53.6)^{a}$ & 6 & 60 & 7.5 & $\mathrm{Mn}^{2+}, \mathrm{Co}^{2+}$ & 20 \\
\hline Thermus sp. IM6501 & $(56.0)^{a}$ & NR & 60 & 8.5 & $\mathrm{Mn}^{2+}$ & 27 \\
\hline Lactobacillus fermentum CGMCC2921 & $(53.4)^{a}$ & NR & 65 & 6.5 & $\mathrm{Mn}^{2+}, \mathrm{Co}^{2+}$ & 21 \\
\hline Bacillus stearothermophilus IAM 11001 & $(55.9)^{a}$ & NR & 65 & 7.5 & $\mathrm{Mn}^{2+}$ & 24 \\
\hline Alicyclobacillus acidocaldarius & $224(56.0)^{a}$ & 4 & 65 & $6.0-6.5$ & $\mathrm{Mn}^{2+}, \mathrm{Co}^{2+}, \mathrm{Mg}^{2+}$ & 25 \\
\hline Thermoanaerobacter mathranii & $220(52.8)^{a}$ & 4 & 65 & 8.0 & $\mathrm{Mn}^{2+}$ & 29 \\
\hline Geobacillus stearothermophilus & $224(56.1)^{a}$ & 4 & 70 & $7.0-7.5$ & $\mathrm{Mn}^{2+}, \mathrm{Co}^{2+}, \mathrm{Mg}^{2+}$ & 19 \\
\hline Geobacillus thermodenitrificans & $230(56.1)^{\mathrm{a}}$ & 4 & 70 & 8.5 & $\mathrm{Mn}^{2+}$ & 22 \\
\hline Acidothermus cellulolytics ATCC 43068 & $(54.8)^{a}$ & NR & 75 & 7.5 & $\mathrm{Mn}^{2+}, \mathrm{Co}^{2+}$ & 28 \\
\hline Bacillus stearothermophilus US100 & $225(56.2)^{a}$ & 4 & 80 & $7.5-8.0$ & $\mathrm{Mn}^{2+\mathrm{b}}, \mathrm{Co}^{2+\mathrm{b}}$ & 23 \\
\hline Thermotoga neapolitana & $(56.7)^{a}$ & NR & 85 & 7.0 & $\mathrm{Mn}^{2+}, \mathrm{Co}^{2+}$ & 30 \\
\hline Thermotoga maritima & $230(56.7)^{a}$ & 4 & 90 & 7.5 & $\mathrm{Mn}^{2+}, \mathrm{Co}^{2+}$ & 31 \\
\hline Anoxybacillus flavithermus TC-06 & $(55.9)^{\mathrm{a}}$ & NR & 95 & $9.5-10.5$ & $\mathrm{Ni}^{2+}$ & 26 \\
\hline
\end{tabular}

NR not reported; ${ }^{a}$ molecular mass of the monomer, calculated from the amino acid sequence; ${ }^{b}$ metal ions required only for thermostability [37]. 


\begin{tabular}{|c|c|c|c|}
\hline Organism & $\begin{array}{l}\text { Conversion } \\
\text { yield (\%) }\end{array}$ & $\begin{array}{l}\text { Conversion } \\
\text { conditions }\end{array}$ & References \\
\hline Arthrobacter sp. 22c & 30 & $50^{\circ} \mathrm{C}, 36 \mathrm{~h}$ & This study \\
\hline Lactobacillus sakei $23 \mathrm{~K}$ & 36 & $40^{\circ} \mathrm{C}, 7 \mathrm{~h}$ & 32 \\
\hline Escherichia coli & 34 & $35^{\circ} \mathrm{C}, 168 \mathrm{~h}$ & 38 \\
\hline Bacillus halodurans & negligible & NR & 19 \\
\hline Lactobacillus plantarum NC8 & 30 & $60^{\circ} \mathrm{C}, 6 \mathrm{~h}$ & 20 \\
\hline Thermus sp. IM6501 & 54 & $60^{\circ} \mathrm{C}, 3$ days & 27 \\
\hline $\begin{array}{l}\text { Lactobacillus fermentum } \\
\text { CGMCC2921 }\end{array}$ & 55 & $65^{\circ} \mathrm{C}, 12 \mathrm{~h}$ & 21 \\
\hline $\begin{array}{l}\text { Bacillus stearothermophilus } \\
\text { IAM } 11001\end{array}$ & 36 & $65^{\circ} \mathrm{C}, 12 \mathrm{~h}$ & 24 \\
\hline Alicyclobacillus acidocaldarius & 44 & $60^{\circ} \mathrm{C}, 6 \mathrm{~h}$ & 25 \\
\hline Thermoanaerobacter mathranii & 25 & $65^{\circ} \mathrm{C}, 24 \mathrm{~h}$ & 29,39 \\
\hline Geobacillus stearothermophilus & 38 & $60^{\circ} \mathrm{C}, 6 \mathrm{~h}$ & 19 \\
\hline Geobacillus thermodenitrificans & 46 & $65^{\circ} \mathrm{C}, 5 \mathrm{~h}$ & 22 \\
\hline $\begin{array}{l}\text { Acidothermus cellulolytics } \\
\text { ATCC } 43068\end{array}$ & 53 & $75^{\circ} \mathrm{C}, 12 \mathrm{~h}$ & 28 \\
\hline $\begin{array}{l}\text { Bacillus stearothermophilus } \\
\text { US100 }\end{array}$ & 48 & $70^{\circ} \mathrm{C}, 7 \mathrm{~h}$ & 23 \\
\hline Thermotoga neapolitana & 68 & $80^{\circ} \mathrm{C}, 20 \mathrm{~h}$ & 30 \\
\hline Thermotoga maritima & 56 & $80^{\circ} \mathrm{C}, 6 \mathrm{~h}$ & 31 \\
\hline $\begin{array}{l}\text { Anoxybacillus flavithermus } \\
\text { TC-06 }\end{array}$ & 60 & $\begin{array}{l}95^{\circ} \mathrm{C}, 1 \mathrm{~h}, \\
\text { borate }^{\mathrm{a}}\end{array}$ & 26 \\
\hline
\end{tabular}

${ }^{a}$ The addition of borate can promote D-tagatose formation [38,39].

Moreover, $P$. pastoris is one of the yeasts to have been widely used for the production and secretion of heterologous proteins [42]. The recombinant yeast strain constructed is able to grow in a medium containing lactose as the sole carbon source. During cultivation, the lactose is hydrolyzed by $\beta$-D-galactosidase, and $D$ glucose is metabolized, while $\mathrm{D}$-galactose is accumulated in the medium. Hence, the $P$. pastoris strain secreting $\beta$ $D$-galactosidase has the potential of being an interesting biocatalyst for the industrial production of $\mathrm{D}$-galactose. Although Grosová et al. have described a method of $D$-galactose production from lactose by means of simultaneous saccharification and fermentation using $\beta$-Dgalactosidase from Kluyveromyces lactis and S. cerevisiae yeast strain entrapped in poly(vinylalcohol) hydrogel [43], the method described in this article would appear to be both less costly and less complicated, since the production and purification of the enzyme have been omitted, as have the immobilization processes.

Moreover, in combination with the Arthrobacter sp. 22c L-arabinose isomerase, the $P$. pastoris strain secreting $\beta$-D-galactosidase $A$. chlorophenolicus provides an innovative method of producing $\mathrm{D}$-tagatose directly from lactose-containing feedstock. The process allows the simultaneous hydrolysis of disaccharide, utilization of $\mathrm{D}$-glucose and isomerization of $\mathrm{D}$-galactose, and thus reduces both the time and the cost of $\mathrm{D}$-tagatose preparation, in comparison to the processes involving the hydrolysis of lactose and separation of D-galactose from a mixture of $\mathrm{D}$-glucose and $\mathrm{D}$-galactose prior to isomerization $[17,33,34]$.

\section{Conclusions}

The new L-arabinose isomerase from psychrotolerant Arthrobacter sp. 22c obtained and characterized in this study has interesting properties. It exhibits optimum activity towards D-galactose at relatively low temperatures ranging from 47 to $52^{\circ} \mathrm{C}$ and in a broad $\mathrm{pH}$ range of between 5 and 9. Moreover, this enzyme does not require the addition of divalent metal ions such as $\mathrm{Mn}^{2+}$ or $\mathrm{Co}^{2+}$ to the reaction mixture for high activity and stability, unlike most of the L-arabinose isomerases described to date.

In this study, a recombinant $P$. pastoris strain secreting A. chlorophenolicus $\beta$-D-galactosidase, which can be used in the production of $\mathrm{D}$-galactose from lactosecontaining materials was also constructed.

Furthermore, the research has produced an innovative approach to the production of D-tagatose from lactose by means of the simultaneous hydrolysis of disaccharide, utilization of D-glucose and isomerization of D-galactose using a recombinant yeast strain secreting $\beta$-D-galactosidase and a recombinant cold-adapted $\mathrm{L}$-arabinose isomerase.

\section{Methods}

\section{Selection of bacterial strains exhibiting L-arabinose} isomerase activity

Twenty bacterial strains of Antarctic microorganisms isolated from soil samples collected in the neighbourhood of the Henryk Arctowski Polish Antarctic Station on King George Island (Southern Shetlands, $62^{\circ} 10^{\prime}$ S, $58^{\circ}$ $28^{\prime} \mathrm{W}$ ) and held in the collections of the Department of Microbiology at Gdańsk University of Technology collection were grown in an LBS medium $(0.5 \%$ peptone K, $0.25 \%$ yeast extract, $1 \%$ marine salt) supplemented with $1 \%$ L-arabinose at $25^{\circ} \mathrm{C}$ for $48 \mathrm{~h}$ with agitation (200 rpm). The cells were then harvested by centrifugation $\left(10,000 \times \mathrm{g}, 20 \mathrm{~min}, 4^{\circ} \mathrm{C}\right)$ and the cell pellets were washed with a $20 \mathrm{mM}$ potassium phosphate buffer with a $\mathrm{pH}$ of 7.0. Cell lysis was achieved by grinding with aluminium oxide (Sigma, USA). After grinding, a $20 \mathrm{mM}$ potassium phosphate buffer with a $\mathrm{pH}$ of 7.0 was added and the samples were centrifuged $\left(10,000 \mathrm{xg}, 30 \mathrm{~min}, 4^{\circ} \mathrm{C}\right)$ to remove cell debris and aluminium oxide. The supernatants thus obtained were mixed with a 5\% (w/v) D-galactose solution in $20 \mathrm{mM}$ potassium phosphate buffer with a $\mathrm{pH}$ of 7.0 in a ratio of 1 to 9 and incubated at $25^{\circ} \mathrm{C}$ for $24 \mathrm{~h}$. An acetonitrile was then added to 
the samples at a ratio of 1 to 1 and the quantities of $\mathrm{D}$-galactose and D-tagatose were determined by HPLC, using an LiChrospher $100 \mathrm{NH}_{2}$ column (Merck, Germany), $80 \%$ (v/v) acetonitrile as a mobile phase and the Agilent 1200 Series Refractive Index Detector.

\section{Identification of the 22c strain}

Genomic DNA from strain 22c, was used as a template to amplify the $16 \mathrm{~S}$ rDNA gene with the primers 16 SFor 5' AGAGTTTGATCCTGGCTCAG 3' and 16SRev 5' ACGGCTACCTTGTTACGACTT 3'. A PCR reaction was performed in a mixture containing $0.2 \mu \mathrm{M}$ of each primer, $0.2 \mu \mathrm{g}$ of genomic DNA, $200 \mu \mathrm{M}$ of each dNTP, and $1 \mathrm{U}$ of DNA polymerase Hypernova (DNA-Gdańsk II, Poland) in $1 \mathrm{x}$ PCR buffer (10 mM Tris- $\mathrm{HCl}$ pH 8.8, $50 \mathrm{mM} \mathrm{KCl}, 3 \mathrm{mM} \mathrm{MgCl} 2,0.15 \%$ Triton X-100). The reaction mixture was incubated for $3 \mathrm{~min}$ at $95^{\circ} \mathrm{C}$, followed by 30 cycles at $95^{\circ} \mathrm{C}$ for $1 \mathrm{~min}, 52^{\circ} \mathrm{C}$ for $1 \mathrm{~min}, 72^{\circ} \mathrm{C}$ for $1.5 \mathrm{~min}$, and a final incubation of $5 \mathrm{~min}$ at $72^{\circ} \mathrm{C}$, using a Mastercycler Gradient (Eppendorf, Germany). The PCR product was purified from an agarose gel band using a DNA Gel-Out kit (A\&A Biotechnology, Poland), cloned into a pJET1.2/blunt vector (Fermentas, Lithuania) and sequenced (Genomed, Poland).

\section{Isolation and sequencing of the ara $A$ gene from Arthrobacter sp. 22c}

The gene encoding the L-arabinose isomerase from Arthrobacter sp. 22c was isolated using the PCR technique. In order to obtain a partial sequence of the $\operatorname{ara} A$ gene from Arthrobacter sp. 22c, sequences encoding genes of the arabinose operons ( $\operatorname{araB}$, $\operatorname{araD}$ and $\operatorname{araA}$ ) of Arthrobacter chlorophenolicus A6 [GenBank: NC_011886], Arthrobacter aurescens TC1 [GenBank: NC_008711] and Arthrobacter sp. FB24 [GenBank: NC_008541], obtained from the GenBank database, were aligned using the ClustalX program, version 1.8. On the basis of the alignment, degenerated primers araDF 5' CTGATGCARAACCACGGCCCSTTCACCATCGGC 3' and araAR 5' GTCTTCCTTGCCGCCRATGCCSAG CGGGTG 3' were designed and synthesized. The PCR reaction was performed in a mixture containing $0.2 \mu \mathrm{M}$ of each primer, $0.2 \mu \mathrm{g}$ of Arthrobacter sp. 22c genomic DNA, $200 \mu \mathrm{M}$ of each dNTP, and $1 \mathrm{U}$ of DNA polymerase Hypernova (DNA-Gdańsk II, Poland) in $1 \mathrm{x}$ PCR buffer $(10 \mathrm{mM}$ Tris- $\mathrm{HCl} \mathrm{pH}$ 8.8, $50 \mathrm{mM} \mathrm{KCl,} 3 \mathrm{mM}$ $\mathrm{MgCl}_{2}, 0.15 \%$ Triton $\left.\mathrm{X}-100\right)$. The reaction mixture was incubated for $3 \mathrm{~min}$ at $95^{\circ} \mathrm{C}$, followed by 30 cycles at $95^{\circ} \mathrm{C}$ for $1 \mathrm{~min}, 72^{\circ} \mathrm{C}$ for $2.5 \mathrm{~min}$, and a final incubation of $5 \mathrm{~min}$ at $72^{\circ} \mathrm{C}$. The PCR product thus obtained was then purified, cloned into the PJET1.2/blunt vector (Fermentas, Lithuania) and sequenced. The GenomeWalker ${ }^{\mathrm{TM}}$ Universal Kit (Clontech Laboratories, USA) was then used to obtain the 3' end of Arthrobacter sp. 22c araA gene. The
Arthrobacter sp. 22c genomic DNA was first digested with the $P v u I I$ restriction endonuclease provided in the kit and ligated to the GenomeWalker Adaptor. Two PCR amplifications were then performed. The primary reaction was carried out using adaptor-ligated genomic DNA fragments as a template and two primers; the outer adaptor primer (AP1) provided in the kit and 22c out primer 5' GCCTCGCTGATGGAGGATTACACCTATGACCTGAC 3', designed on the basis of the partial sequence of Arthrobacter sp. 22c araA gene previously obtained. The reaction mixture also contained $200 \mu \mathrm{M}$ dNTPs and $1 \mathrm{U}$ of DNA polymerase Marathon (A\&A Biotechnology, Poland) in $1 \mathrm{x}$ Marathon buffer. DNA amplification was performed using the following parameters: $\left(94^{\circ} \mathrm{C}-0.5 \mathrm{~min}, 72^{\circ} \mathrm{C}-\right.$ $3 \mathrm{~min}) 7 \mathrm{cycles},\left(94^{\circ} \mathrm{C}-0.5 \mathrm{~min}, 67^{\circ} \mathrm{C}-3 \mathrm{~min}\right) 32$ cycles and $67^{\circ} \mathrm{C}$ for $7 \mathrm{~min}$ after the final cycle. The primary PCR mixture was then used as a template for a secondary PCR with the nested adaptor primer (AP2) provided in the kit and 22c32c in primer 5' GATCCTSGGCGCG CACATGCTKGAGG 3'. The nested PCR mixture also contained $200 \mu \mathrm{M}$ dNTPs and $1 \mathrm{U}$ of DNA polymerase Marathon in 1 x Marathon buffer. DNA amplification was performed using the following parameters: $\left(94^{\circ} \mathrm{C}-\right.$ $\left.0.5 \mathrm{~min}, 72^{\circ} \mathrm{C}-3 \mathrm{~min}\right) 5$ cycles, $\left(94^{\circ} \mathrm{C}-0.5 \mathrm{~min}, 67^{\circ} \mathrm{C}-\right.$ $3 \mathrm{~min}$ ) 20 cycles and $67^{\circ} \mathrm{C}$ for $7 \mathrm{~min}$ after the final cycle. In the third step the nested PCR product was purified from an agarose gel band, cloned into the pJET1.2/blunt vector and sequenced. Following this, two fragments of Arthrobacter sp. 22c genomic DNA sequences were alignment and the full sequence of the Arthrobacter sp. $22 \mathrm{c}$ ara $A$ gene was obtained.

\section{Construction of the $E$. coli expression system for the production of Arthrobacter sp. 22c L-arabinose isomerase} On the basis of the known sequence of the $\operatorname{araA}$ gene from Arthrobacter sp. 22c (GenBank Accession No. JN642528), the specific primers for PCR amplification were designed and synthesized. The gene was amplified using forward primer F22cNdemut 5' ATACATATGAG CAAAGCCTATGAATCCAAGGA 3', and reverse primer R22cHind 5' CTGAAGCTTACAGGCCCTGCGCCA GACGGTAGTACGCCTGG 3' (containing NdeI and HindIII recognition sites, underlined). The start and stop codons are given in bold. The PCR reaction mixture contained $0.2 \mu \mathrm{M}$ of each primer, $0.2 \mu \mathrm{g}$ of Arthrobacter sp. 22c genomic DNA, $200 \mu \mathrm{M}$ of each dNTP, and $1 \mathrm{U}$ of DNA polymerase Hypernova (DNA-Gdańsk II, Poland) in $1 \mathrm{x}$ PCR buffer (10 mM Tris- $\mathrm{HCl} \mathrm{pH} 8.8$, $50 \mathrm{mM} \mathrm{KCl}, 3 \mathrm{mM} \mathrm{MgCl} 2,0.15 \%$ Triton X-100). The reaction mixture was incubated for $3 \mathrm{~min}$ at $95^{\circ} \mathrm{C}$, followed by 30 cycles at $95^{\circ} \mathrm{C}$ for $1 \mathrm{~min}, 60^{\circ} \mathrm{C}$ for $1 \mathrm{~min}$, $72^{\circ} \mathrm{C}$ for $1.5 \mathrm{~min}$ and a final incubation of $5 \mathrm{~min}$ at $72^{\circ} \mathrm{C}$ using a Mastercycler Gradient (Eppendorf, Germany). The PCR product was then purified from an agarose gel 
band using a DNA Gel-Out kit (A\&A Biotechnology, Poland), digested with $\mathrm{NdeI}$ and HindIII endonucleases (Fermentas, Lithuania) and cloned into a pET-30 Ek/LIC vector (Novagen, England) digested with the same restriction enzymes. The resulting recombinant plasmid pET30araA22c containing the Arthrobacter sp. 22c Larabinose isomerase gene under the control of the T7 promoter was used to transform chemically competent E. coli BL21(DE3)pLysS cells (Novagen, England).

\section{Production and purification of the recombinant Arthrobacter sp. 22c L-arabinose isomerase}

Expression of the Arthrobacter sp. 22c L-arabinose isomerase gene was performed in the E. coli BL21(DE3)pLysS cells carrying the pET30araA22c plasmid. The cells were grown at $30^{\circ} \mathrm{C}$ in 1 litre of $\mathrm{LB}$ medium (1\% peptone $\mathrm{K}$, $0.5 \%$ yeast extract, $1 \% \mathrm{NaCl}$ ) containing $25 \mu \mathrm{g} \mathrm{mL}$ kanamycin and $34 \mu \mathrm{g} \mathrm{mL} \mathrm{L}^{-1}$ chloramphenicol to $\mathrm{OD}_{600}$ of 0.4. $1 \mathrm{M}$ isopropyl $\beta$-D-1-thiogalactopyranoside (IPTG) was then added to the final concentration of $1 \mathrm{mM}$ and cultivation was continued for $6 \mathrm{~h}$. The culture was then centrifuged $\left(5,000 \mathrm{xg}, 10 \mathrm{~min}, 4^{\circ} \mathrm{C}\right)$, the cell pellet was resuspended in $50 \mathrm{~mL}$ of buffer A $(20 \mathrm{mM}$ potassium phosphate buffer $\mathrm{pH} 6.0$ containing $50 \mathrm{mM} \mathrm{KCl}$ ), and the cells were disrupted by sonication. After centrifugation $\left(10,000 \mathrm{xg}, 30 \mathrm{~min}, 4^{\circ} \mathrm{C}\right)$, the supernatant was applied onto Fractogel ${ }^{\circledR}$ EMD DEAE weak anion exchanger purchased from Merck (Germany) $(60 \mathrm{~mL}$ column) equilibrated with four volumes of buffer $\mathrm{A}$. The column was washed with three volumes of buffer A and the recombinant $\mathrm{L}$-arabinose isomerase was eluted with a linear gradient of potassium chloride $(50-1500 \mathrm{mM})$ in the same buffer (four volumes of the column). Fractions containing L-arabinose isomerase were pooled, dialyzed against buffer $\mathrm{A}$ and loaded onto Fractogel ${ }^{\circledR}$ EMD TMAE (Merck) strong anion exchanger. The $40 \mathrm{~mL}$ column had previously been equilibrated with four volumes of buffer $\mathrm{A}$ and the elution was performed with a linear gradient of potassium chloride $(50-1250 \mathrm{mM})$ in the same buffer (four volumes of the column). Fractions containing Arthrobacter sp. 22c L-arabinose isomerase were pooled, dialyzed against $20 \mathrm{mM}$ potassium phosphate buffer $\mathrm{pH} 7.0$ and stored at $4^{\circ} \mathrm{C}$ until used. The concentration of purified protein was determined by the Bradford method [44] using bovine serum albumin (BSA) as a standard.

\section{Characterization of the Arthrobacter sp. 22c L-arabinose isomerase}

The molecular mass of the native Arthrobacter sp. 22c $\mathrm{L}$-arabinose isomerase was estimated by gel filtration using bovine thyroglobulin $(669 \mathrm{kDa})$, apoferritin from horse spleen $(443 \mathrm{kDa}), \beta$-amylase from sweet potato $(200 \mathrm{kDa})$, alcohol dehydrogenase from yeast $(150 \mathrm{kDa})$, bovine serum albumin $(66 \mathrm{kDa})$ and carbonic anhydrase from bovine erythrocytes $(29 \mathrm{kDa})$ purchased from Sigma (USA) as standards. The purified enzyme was loaded onto a Superdex ${ }^{\text {TM }} 200$ 10/300 GL column (Amersham Biosciences $\mathrm{AB}$, Sweden) and the elution was performed using $20 \mathrm{mM}$ potassium phosphate buffer $\mathrm{pH} 7.0$ containing $150 \mathrm{mM} \mathrm{KCl}$.

The activity of purified Arthrobacter sp. 22c Larabinose isomerase was determined using $\mathrm{D}$-galactose as a substrate. The isomerization reaction was halted by the addition of acetonitrile (1:1) and the quantity of D-tagatose was determined by HPLC using a LiChrospher $100 \mathrm{NH}_{2}$ column, 80\% (v/v) acetonitrile as a mobile phase and a refractive index detector. One unit of L-arabinose isomerase activity was defined as being the quantity of enzyme catalysing the formation of $1 \mu \mathrm{mol} \mathrm{D}$-tagatose per min at $50^{\circ} \mathrm{C}$ and $\mathrm{pH}$ 7.0.

To determine the effect of temperature on the Larabinose isomerase's activity, the enzyme $\left(0.2 \mathrm{mg} \mathrm{mL}^{-1}\right)$ was incubated in $20 \mathrm{mM}$ potassium phosphate buffer $\mathrm{pH}$ 7.0 containing $4 \%(\mathrm{w} / \mathrm{v})$ substrate at 25 to $65^{\circ} \mathrm{C}$ for $12 \mathrm{~h}$.

For $\mathrm{pH}$-activity studies, isomerization reactions were performed in $20 \mathrm{mM}$ citrate buffer $\mathrm{pH} 5$ to $6,20 \mathrm{mM}$ potassium phosphate buffer $\mathrm{pH} 6$ to 8 and $20 \mathrm{mM}$ Tris$\mathrm{HCl}$ buffer $\mathrm{pH} 8$ to 9 at $50^{\circ} \mathrm{C}$.

The effects of various metal ions on recombinant enzyme activity were measured by assaying the enzyme in $20 \mathrm{mM}$ HEPES $\mathrm{pH} 7.0$ containing 1,5 and $10 \mathrm{mM}$ $\mathrm{CaCl}_{2} \cdot 2 \mathrm{H}_{2} \mathrm{O}, \mathrm{CoCl}_{2} \cdot 6 \mathrm{H}_{2} \mathrm{O}, \mathrm{MgCl}_{2} \cdot 6 \mathrm{H}_{2} \mathrm{O}, \mathrm{MnCl}_{2} \cdot 4 \mathrm{H}_{2} \mathrm{O}$ or $\mathrm{NiCl}_{2} \cdot 6 \mathrm{H}_{2} \mathrm{O}$ at $50^{\circ} \mathrm{C}$.

For the thermal stability studies, the enzyme was incubated at various temperatures for different periods of time and the residual L-arabinose isomerase activity was then measured at $50^{\circ} \mathrm{C}$ and $\mathrm{pH}$ 7.0.

To determine the kinetic parameters, the isomerization reactions were performed in $20 \mathrm{mM}$ potassium phosphate buffer pH 7.0 containing $50-500 \mathrm{mM} \mathrm{D-}$ galactose at $50^{\circ} \mathrm{C}$ for $30 \mathrm{~min}$. The $K_{\mathrm{m}}$ and $V_{\max }$ values were obtained using the Lineweaver-Burk equation.

Analysis of the isomerization of D-galactose to Dtagatose by the Arthrobacter sp. 22c L-arabinose isomerase was performed in a mixture containing $4 \%(\mathrm{w} / \mathrm{v}) \mathrm{D}-$ galactose and $0.2 \mathrm{mg} \mathrm{mL} \mathrm{m}^{-1} \mathrm{~L}$-arabinose isomerase in $20 \mathrm{mM}$ potassium phosphate buffer $\mathrm{pH}$ 7.0. The reaction mixture was incubated at $50^{\circ} \mathrm{C}$ for $72 \mathrm{~h}$. After each 12-hour period, $1 \mathrm{~mL}$ samples were collected and the isomerization reaction was halted by the addition of acetonitrile. D-Tagatose and D-galactose concentrations were determined by HPLC.

\section{Construction of the recombinant $P$. pastoris strain secreting $\beta$-D-galactosidase $A$. chlorophenolicus} Arthrobacter chlorophenolicus (DSM 12829) was purchased from Deutsche Sammlung von Mikroorganismen 
und Zellkulturen (Germany). The primers used for PCR amplification of the $\beta$-D-galactosidase gene were designed on the basis of the known A. chlorophenolicus $\beta$-D-galactosidase gene sequence [GenBank: NC_011886 (3472060..3474075)]. These primers were FAchBSal 5' ATAGTCGACAAAAGAATGGCAACGCAGGAAATTAA CCGTCCG 3' containing SalI recognition site (underlined) and RAchBXbH 5'CTGAAGCTTCTAGACTAGCCCT CCCTGATCACCGCAATGC 3' containing X $b a \mathrm{I}$ and HindIII recognition sites (underlined). The start and stop codons are given in bold. The PCR reaction mixture contained $0.2 \mu \mathrm{M}$ of each primer, $0.2 \mu \mathrm{g}$ of A. chlorophenolicus genomic DNA, $200 \mu \mathrm{M}$ of each dNTP, and $1 \mathrm{U}$ of DNA polymerase Hypernova (DNA-Gdańsk II, Poland) in $1 \mathrm{x}$ PCR buffer $(10 \mathrm{mM}$ Tris- $\mathrm{HCl} \mathrm{pH} 8.8,50 \mathrm{mM}$ $\mathrm{KCl}, 3 \mathrm{mM} \mathrm{MgCl}_{2}, 0.15 \%$ Triton X-100). The reaction mixture was incubated for $3 \mathrm{~min}$ at $95^{\circ} \mathrm{C}$, followed by 30 cycles at $95^{\circ} \mathrm{C}$ for $1 \mathrm{~min}, 68^{\circ} \mathrm{C}$ for $1 \mathrm{~min}, 72^{\circ} \mathrm{C}$ for $2 \mathrm{~min}$ and a final incubation of $5 \mathrm{~min}$ at $72^{\circ} \mathrm{C}$ using a Mastercycler Gradient (Eppendorf, Germany). The PCR product thus obtained was purified from an agarose gel band, digested with SalI and XbaI endonucleases (Fermentas, Lithuania) and cloned into a pGAPZ $\alpha$ B vector (Invitrogen, USA) previously digested with $X h o \mathrm{I}$ and $X b a \mathrm{I}$ restriction enzymes. The SalI and XhoI endonucleases leave compatible protruding DNA ends. The resulting recombinant plasmid pGAPZ $\alpha-\beta$-galAch containing the $A$. chlorophenolicus $\beta$-D-galactosidase gene was then linearized by $\mathrm{Xma}$ II endonuclease and used to transform $P$. pastoris GS115 competent cells using Pichia EasyComp $^{\mathrm{TM}}$ Transformation Kit (Invitrogen). The secretion of $A$. chlorophenolicus $\beta$-D-galactosidase by the recombinant $P$. pastoris strain harbouring $\mathrm{pGAPZ} \alpha-\beta-$ galAch plasmid was confirmed in the reaction with $o$ nitrophenyl $\beta$-D-galactopyranoside (ONPG). The recombinant yeast strain was grown in a YPD medium $(2 \%$ peptone $\mathrm{K}, 1 \%$ yeast extract, $2 \% \mathrm{D}$-glucose) at $30^{\circ} \mathrm{C}$ for $72 \mathrm{~h}$ and the enzyme activity was then determined in the medium obtained after centrifugation of the culture $\left(5,000 \times g, 10 \mathrm{~min}, 4^{\circ} \mathrm{C}\right) .0 .25 \mathrm{~mL}$ of postcultivation medium was added to $0.75 \mathrm{~mL}$ of ONPG solution $\left(1 \mathrm{mg} \mathrm{mL}^{-1}\right.$ in $20 \mathrm{mM}$ potassium phosphate buffer $\mathrm{pH} 7.0)$ and the mixture was incubated at $30^{\circ} \mathrm{C}$ for $15 \mathrm{~min}$. The hydrolysis reaction was then halted by the addition of $0.5 \mathrm{~mL} 1 \mathrm{M} \mathrm{Na}_{2} \mathrm{CO}_{3}$ and the absorbance of the mixture was measured at $405 \mathrm{~nm}$. The reference sample contained fresh YPD medium instead of postcultivation medium.

\section{Production of D-galactose using the recombinant $P$. pastoris strain secreting $\beta$-D-galactosidase A. chlorophenolicus}

The recombinant $P$. pastoris strain harbouring the pGAPZ $\alpha$ - $\beta$-galAch plasmid was used for D-galactose production from whey permeate. The whey permeate powder, containing $80 \%(\mathrm{w} / \mathrm{w})$ lactose, was purchased from the OSTROWIA Mazovian Dairy Co-operative (Poland). The recombinant yeast strain was grown in the YPD medium (2\% peptone $\mathrm{K}, 1 \%$ yeast extract, $2 \% \mathrm{D}$ glucose), at $30^{\circ} \mathrm{C}$ for $30 \mathrm{~h}$ with agitation $(250 \mathrm{rpm})$. This culture was used to inoculate $(15 \% \mathrm{v} / \mathrm{v})$ whey permeate solutions containing $60-300 \mathrm{~g} \mathrm{~L}^{-1}$ lactose. The cultures were then grown for $168 \mathrm{~h}$ at $30^{\circ} \mathrm{C}$. After each 24-hour period, $1 \mathrm{~mL}$ samples were collected and the hydrolysis of lactose catalyzed by the secreted A. chlorophenolicus $\beta$-D-galactosidase was halted by the addition of $17 \mu \mathrm{L}$ of $20 \% \mathrm{H}_{2} \mathrm{SO}_{4}$. The quantities of lactose and D-galactose in the supernatants were determined by HPLC using an Aminex HPX-87H column (Bio-Rad, USA), $5 \mathrm{mM}$ $\mathrm{H}_{2} \mathrm{SO}_{4}$ as a mobile phase and an Agilent 1200 Series Refractive Index Detector.

\section{Production of D-tagatose using the recombinant Pichia pastoris strain secreting $\beta$-D-galactosidase A. chlorophenolicus and the recombinant L-arabinose isomerase from Arthrobacter sp. 22c}

To produce D-tagatose, a whey permeate solution containing $130 \mathrm{~g} \mathrm{~L}^{-1}$ lactose was inoculated with $30 \mathrm{~h}$ culture of the recombinant $P$. pastoris strain harbouring pGAPZ $\alpha-\beta$-galAch plasmid $(15 \% \mathrm{v} / \mathrm{v})$ and incubated for $48 \mathrm{~h}$ at $30^{\circ} \mathrm{C}$ with agitation $(250 \mathrm{rpm}) .0 .2 \mathrm{mg} \mathrm{mL}^{-1}$ of the purified Arthrobacter sp. 22c L-arabinose isomerase was then added and cultivation was continued for $120 \mathrm{~h}$. After each 24-hour period, $1 \mathrm{~mL}$ samples were taken and centrifuged $\left(10,000 \mathrm{xg}, 10 \mathrm{~min}, 4^{\circ} \mathrm{C}\right)$. The enzymatic reactions were halted by heating for $10 \mathrm{~min}$ at $95^{\circ} \mathrm{C}$. The samples were then cooled and filtered through a $0.45 \mu \mathrm{m}$ filter. The quantities of lactose, D-galactose and D-tagatose were determined by HPLC using an Aminex HPX-87C column (Bio-Rad, USA), deionized water as a mobile phase and an Agilent 1200 Series Refractive Index Detector.

All the measurements were taken and the experiments carried out in triplicate.

\section{Nucleotide sequences accession numbers}

The 16S rDNA and L-arabinose isomerase gene sequences reported in this article have been deposited in the GenBank database and assigned Accession Nos. JN642527 and JN642528, respectively.

\footnotetext{
Abbreviations

L-Al: L-Arabinose isomerase; 22cAl: L-Arabinose isomerase from Arthrobacter sp. 22c; EDTA: Ethylenediaminetetraacetic acid; GAP: Glyceraldehyde 3-phosphate dehydrogenase; HEPES: N-(2-Hydroxyethyl)piperazine-N'(2-ethanesulfonic acid); HPLC: High performance liquid chromatography; IPTG: Isopropyl $\beta$-D-1-thiogalactopyranoside; ONPG: o-Nitrophenyl $\beta$-D-galactopyranoside.
} 


\section{Competing interest}

The authors declare that they have no competing interests.

\section{Authors' contributions}

MW designed the study, performed the experiments and drafted the manuscript, JK coordinated the study and revised the manuscript. Both authors have read and approved the final version of manuscript.

\section{Acknowledgements}

The authors would like to thank Professor Marianna Turkiewicz of the Institute of Technical Biochemistry at the Technical University of Łódź for providing the Antarctic soil samples.

Received: 22 February 2012 Accepted: 18 August 2012

Published: 23 August 2012

\section{References}

1. Hirst EL, Hough L, Jones JKN: Composition of the gum of Sterculia setigera: occurrence of D-tagatose in nature. Nature 1949, 163:177.

2. Troyano E, Villamiel M, Olano A, Sanz J, Martinez-Castro I: Monosaccharides and myo-inositol in commercial milks. J Agric Food Chem 1996, 44:815-817.

3. Mendoza MR, Olano A, Villamiel M: Chemical indicators of heat treatment in fortified and special milks. J Agric Food Chem 2005, 53:2995-2999.

4. Levin GV, Zehner LR, Saunders JP, Beadle JR: Sugar substitutes: their energy values, bulk characteristics, and potential health benefits. Am J Clin Nutr 1995, 62:1161S-1168S.

5. Levin GV: Tagatose, the new GRAS sweetener and health product. J Med Food 2002, 5:23-36.

6. Wheeler ML, Pi-Sunyer FX: Carbohydrate issues: type and amount. J Am Diet Assoc 2008, 108:S34-S39.

7. Lu Y, Levin GV, Donner TW: Tagatose, a new antidiabetic and obesity control drug. Diabetes Obes Metab 2008, 10:109-134.

8. Izumori K, Miyoshi T, Tokuda S, Yamabe K: Production of D-tagatose from dulcitol by Arthrobacter globiformis. Appl Environ Microbiol 1984, 46:1055-1057.

9. Izumori K, Tsuzaki K: Production of D-tagatose from D-galactitol by Mycobacterium smegmatis. J Ferment Technol 1988, 66:225-227.

10. Muniruzzaman S, Tokunaga $\mathrm{H}$, Izumori K: Isolation of Enterobacter agglomerans strain 221e from soil, a potent D-tagatose producer from galactitol. J Ferment Bioeng 1994, 78:145-148.

11. Manzoni M, Rollini M, Bergomi S: Biotransformation of D-galactitol to tagatose by acetic acid bacteria. Process Biochem 2001, 36:971-977.

12. Rollini M, Manzoni M: Bioconversion of D-galactitol to tagatose and dehydrogenase activity induction in Gluconobacter oxydans. Process Biochem 2005, 40:437-444.

13. Yoshihara K, Shinohara Y, Hirotsu T, Izumori K: Bioconversion of D-psicose to D-tagatose and D-talitol by Mucoraceae fungi. J Biosci Bioeng 2006, 101:219-222.

14. Takeshita K, Suga A, Takada G, Izumori K: Mass production of D-psicose from D-fructose by a continuous bioreactor system using immobilized D-tagatose 3-epimerase. J Biosci Bioeng 2000, 90:453-455.

15. Zhang L, Mu W, Jiang B, Zhang T: Characterization of D-tagatose3-epimerase from Rhodobacter sphaeroides that converts D-fructose into D-psicose. Biotechnol Lett 2009, 31:857-862.

16. Kim HJ, Hyun EK, Kim YS, Lee YJ, Oh DK: Characterization of an Agrobacterium tumefaciens D-psicose 3-epimerase that converts D-fructose to D-psicose. Appl Environ Microbiol 2006, 72:981-985.

17. Beadle JR, Saunders JP, Wajda TJ Jr: Process for manufacturing tagatose; 1991. US Patent 5,002,612.

18. Yoon SH, Kim P, Oh DK: Properties of L-arabinose isomerase from Escherichia coli as biocatalyst for tagatose production. World J Microbiol Biotechnol 2003, 19:47-51.

19. Lee DW, Choe EA, Kim SB, Eom SH, Hong YH, Lee SJ, Lee HS, Lee DY, Pyun YR: Distinct metal dependence for catalytic and structural functions in the $\mathrm{L}$-arabinose isomerases from the mesophilic Bacillus halodurans and the thermophilic Geobacillus stearothermophilus. Arch Biochem Biophys 2005, 434:333-343.

20. Chouayekh H, Bejar W, Rhimi M, Jelleli K, Mseddi M, Bejar S: Characterization of an L-arabinose isomerase from the Lactobacillus plantarum NC8 strain showing pronounced stability at acidic pH. FEMS Microbiol Lett 2007, 277:260-267.

21. Xu Z, Qing Y, Li S, Feng X, Xu H, Ouyang P: A novel L-arabinose isomerase from Lactobacillus fermentum CGMCC2921 for D-tagatose production: Gene cloning, purification and characterization. J Mol Catal B: Enzym 2011, 70:1-7.

22. Kim HJ, Oh DK: Purification and characterization of an L-arabinose isomerase from an isolated strain of Geobacillus thermodenitrificans producing D-tagatose. J Biotechnol 2005, 120:162-173.

23. Rhimi M, Bejar S: Cloning, purification and biochemical characterization of metallic-ions independent and thermoactive L-arabinose isomerase from the Bacillus stearothermophilus US100 strain. Biochim Biophys Acta 2006, 1760:191-199.

24. Cheng $L, M u$ W, Jiang B: Thermostable L-arabinose isomerase from Bacillus stearothermophilus IAM 11001 for D-tagatose production: gene cloning, purification and characterization. J Sci Food Agric 2010, 90:1327-1333.

25. Lee SJ, Lee DW, Choe EA, Hong YH, Kim SB, Kim BC, Pyun YR: Characterization of a thermoacidophilic $L$-arabinose isomerase from Alicyclobacillus acidocaldarius: role of Lys-269 in pH optimum. Appl Environ Microbiol 2005, 71:7888-7896.

26. Li Y, Zhu Y, Liu A, Sun Y: Identification and characterization of a novel L-arabinose isomerase from Anoxybacillus flavithermus useful in D-tagatose production. Extremophiles 2011, 15:441-450.

27. Kim JW, Kim YW, Roh HJ, Kim HY, Cha JH, Park KH, Park CS: Production of tagatose by a recombinant thermostable L-arabinose isomerase from Thermus sp. IM6501. Biotechnol Lett 2003, 25:963-967.

28. Cheng L, Mu W, Zhang T, Jiang B: An L-arabinose isomerase from Acidothermus cellulolytics ATCC 43068: cloning, expression, purification, and characterization. Appl Microbiol Biotechnol 2010, 86:1089-1097.

29. Jørgensen F, Hansen OC, Stougaard P: Enzymatic conversion of D-galactose to D-tagatose: heterologous expression and characterisation of a thermostable L-arabinose isomerase from Thermoanaerobacter mathranii. Appl Microbiol Biotechnol 2004, 64:816-822.

30. Kim BC, Lee YH, Lee HS, Lee DW, Choe EA, Pyun YR: Cloning, expression and characterization of $\mathrm{L}$-arabinose isomerase from Thermotoga neapolitana: bioconversion of D-galactose to D-tagatose using the enzyme. FEMS Microbiol Lett 2002, 212:121-126.

31. Lee DW, Jang HJ, Choe EA, Kim BC, Lee SJ, Kim SB, Hong YH, Pyun YR: Characterization of a thermostable L-arabinose (D-galactose) isomerase from the hyperthermophilic eubacterium Thermotoga maritima. App/ Environ Microbiol 2004, 70:1397-1404.

32. Rhimi M, Ilhammami R, Bajic G, Boudebbouze S, Maguin E, Haser R, Aghajari $\mathrm{N}$ : The acid tolerant $\mathrm{L}$-arabinose isomerase from the food grade Lactobacillus sakei $23 \mathrm{~K}$ is an attractive D-tagatose producer. Biores Technol 2010, 101:9171-9177.

33. Ibrahim OO, Spradlin JE: Process for manufacturing D-tagatose; 2000. US Patent 6,057,135.

34. Bertelsen H, Eriknauer K, Bottcher K, Christensen HJS, Stougaard P, Hansen OC, Jorgensen F: Process for manufacturing of tagatose; 2006. US Patent 6,991,923.

35. Manjasetty BA, Chance MR: Crystal structure of Escherichia coli L-arabinose isomerase (ECAI), the putative target of biological tagatose production. J Mol Biol 2006, 360:297-309.

36. Rhimi M, Juy M, Aghajari N, Haser R, Bejar S: Probing the essential catalytic residues and substrate affinity in the thermoactive Bacillus stearothermophilus US100 L-arabinose isomerase by site-directed mutagenesis. J Bacteriol 2007, 189:3556-3563.

37. Patrick JW, Lee N: Subunit structure of L-arabinose isomerase from Escherichia coli. J Biol Chem 1969, 244:4277-4283.

38. Roh HJ, Yoon SH, Kim P: Preparation of L-arabinose isomerase originated from Escherichia coli as a biocatalyst for D-tagatose production. Biotechnol Lett 2000, 22:197-199.

39. Hansen OC, Jørgensen F, Stougaard P, Bertelsen H, Bøttcher K, Christensen HJS, Eriknauer K: Thermostable isomerase and use hereof, in particular for producing tagatose; 2006. US Patent 7,052,898.

40. Oh HJ, Kim HJ, Oh DK: Increase in D-tagatose production rate by site-directed mutagenesis of L-arabinose isomerase from Geobacillus thermodenitrificans. Biotechnol Lett 2006, 28:145-149.

41. Westerberg K, Elväng AM, Stackebrandt E, Jansson JK: Arthrobacter chlorophenolicus sp. nov., a new species capable of degrading high concentration of 4-chlorophenol. Int J Syst Evol Microb 2000, 50:2083-2092. 
42. Macauley-Patrick S, Fazenda ML, McNeil B, Harvey LM: Heterologous protein production using the Pichia pastoris expression system. Yeast 2005, 22:249-270.

43. Grosová Z, Rosenberg M, Gdovin M, Sláviková L, Rebroš M: Production of D-galactose using $\beta$-galactosidase and Saccharomyces cerevisiae entrapped in poly(vinylalcohol) hydrogel. Food Chem 2009, 116:96-100.

44. Bradford MM: A rapid and sensitive method for the quantitation of microgram quantities of protein utilizing the principle of protein-dye binding. Anal Biochem 1976, 72:248-254.

doi:10.1186/1475-2859-11-113

Cite this article as: Wanarska and Kur: A method for the production of D-tagatose using a recombinant Pichia pastoris strain secreting $\beta$-D-galactosidase from Arthrobacter chlorophenolicus and a recombinant $\mathrm{L}$-arabinose isomerase from Arthrobacter sp. 22c. Microbial Cell Factories 2012 11:113.

\section{Submit your next manuscript to BioMed Central and take full advantage of:}

- Convenient online submission

- Thorough peer review

- No space constraints or color figure charges

- Immediate publication on acceptance

- Inclusion in PubMed, CAS, Scopus and Google Scholar

- Research which is freely available for redistribution 